\title{
The Effectiveness of Dynamic Geometry Software Applications in Learning Mathematics: A Meta- Analysis Study
}

\author{
https://doi.org/10.3991/ijim.v15i02.18853 \\ Dadang Juandi $\left({ }^{凶}\right)$, Yaya S. Kusumah \\ Universitas Pendidikan Indonesia, Bandung, Indonesia \\ dadang . juandi@upi .edu \\ Maximus Tamur \\ Universitas Katolik Indonesia Santu Paulus, Ruteng, Indonesia \\ Krisna S. Perbowo \\ University of Warwick, Warwick, United Kingdom \\ Muhammad Daut Siagian \\ Universitas Islam Sumatera Utara, Medan, Indonesia \\ Rini Sulastri \\ Universitas Serambi Mekkah, Aceh, Indonesia \\ Habibi R. P. Negara \\ Universitas Islam Negeri Mataram, Mataram, Indonesia
}

\begin{abstract}
Hundreds of studies on Dynamic Geometry Software (DGS) influence on mathematics learning with mixed results have been found in the literature. Correspondingly, this meta-analysis study was conducted to assess the overall impact of DGS and analyze the characteristics of the identified studies to help educators decide under what conditions the use of DGS would achieve a higher level of effectiveness. This meta-analysis study investigated 57 effect sizes drawn from 50 journal articles and international proceedings between 2010 and 2020, using the Comprehensive Meta-Analysis (CMA) program as a calculation tool. Meanwhile, the Hedges coefficient is used to calculate the effect size at the $95 \%$ confidence level. Based on a random-effect model with a standard error of 0.09 , the analysis found an overall effect size of 1.07. This means that learning using DGS has a relatively high positive effect on math skills. Analysis of the study's characteristics revealed that the DGS used was more effective by considering sample size, student-computer ratio, and education level. These facts can help educators use DGS in the future. Finally, the study's implications and limitations are discussed, providing crucial information for further meta-analysis studies on DGS's impact.
\end{abstract}

Keywords - Dynamic Geometry Software, Meta-analysis, Mathematical ability, Study Characteristics 


\section{Introduction}

The advancement in computer technology has led to the application of software development in learning [1]-[3]. This further motivates teachers to take steps to integrate computers into the educational environment [4], [5], in order to improve the effectiveness and quality of the education system [6]-[8]. This development also provides additional training and opportunities for students to explore their problemsolving attributes by seeking alternative solutions due to the unlimited computer use capabilities in the learning [9]-[11].

The use of computers has quickly attracted the interest of teachers and researchers in teaching mathematics [12]-[16] and one of the most widely applied software is Dynamic Geometry Software (DGS). This software allows users to make geometric figures and measure several variables from them to determine their properties, drag numbers through the screen, produce geometric constructions, hypotheses, and test them to make generalizations [17], [18]. Several studies have, however, been conducted to determine the effectiveness of DGS in mathematics classes [19]-[26].

Some studies have been conducted to examine DGS's effectiveness on students' mathematical abilities at various levels of education in Indonesia with several inconsistent results. For example, [10]- [31] showed the use of DGS was more effective in improving students' mathematical abilities than conventional methods of learning while [32]-[35] found that it was not better. Currently, there has not been a comprehensive evaluation of the usefulness of DGS on students' mathematical abilities have not been explored much. Meanwhile, educators and stakeholders need accurate information to determine the appropriate conditions for using DGS to achieve higher effectiveness levels.

It is possible to fill this gap by undertaking a study that combines several quantitative findings to provide useful information for practice or policy [36], [37]. This method has been analyzed to consider its implications [38], and up to 2020, no research was found to have combined the results obtained in other studies to draw an objective conclusion. However, reviewing the literature in several studies allows for variation in results but also provides subjective conclusions [39], [40].

Meta-analysis is an objective method for reviewing the literature because of the use of its effect size as the unit of analysis [41]-[43]. Moreover, the effect sizes from each study would be combined to obtain an overall effect size [43], [44]. This technique eliminates the subjective interpretation of several empirical reports on the same topic [45], [46]. Finally, statistical procedures were used to determine the differences in DGS effectiveness based on study characteristics.

Our previous meta-analysis research evaluated the effectiveness of constructivismbased mathematics learning [44] and mathematics software-based mathematics learning [37]. We found that study characteristics such as study class and sample size influenced the effect sizes of the two models on students' mathematical abilities. However, study characteristics such as the ratio between students and computers used have not been investigated. Even though several meta-analyses including [47]-[54] has been focused on computer effectiveness in general, only one study [55] focused exclusively on the effectiveness of DGS on students' mathematical achievement. How- 
ever, it has not included the ratio between students and computers used as characteristics of the analyzed studies.

This study intends to complement previous research with the aim of (1) assessing the impact of using DGS on students' overall mathematical abilities and (2) determining differences in effectiveness based on research characteristics. These are necessary to help educators decide the most suitable conditions to use the software in improving students' mathematical abilities. These goals were achieved by analyzing primary studies conducted on DGS effectiveness on students' mathematical abilities using meta-analysis as a research tool with the following questions being the center of focus:

- Does the use of DGS in mathematics learning produce a large effect size on mathematical abilities than conventional approaches?

- Are there differences in effectiveness between DGS applied based on the following research years: (a) 2010-2012, (b) 2013-2015, (c) 2016-2018, and (d) 2019-2020?

- Are there differences in effectiveness between the DGS implemented at the following educational levels: (a) Junior High Schools, (b) High and Vocational Schools, and (c) higher institutions?

- Are there differences in effectiveness between DGS applied based on the following sample sizes: (a) less or equal to 30, and (b) more than 30 ?

- Are there differences in effectiveness between the following types of DGS: (a) GeoGebra, (b) Cabri, (c) Sketchpad, and (d) Wingeom?

- Are there differences in effectiveness between DGS applied based on students' ratio to computers in the following settings: (a) individuals and (b) Groups?

\section{Methodology}

\subsection{Research design}

This study was conducted to statistically evaluate and interpret the findings of primary studies that have been conducted on the effect of DGS in mathematics learning on students' mathematical abilities in Indonesia. This involves using a meta-analysis method with statistical analysis of quantitative data from individual studies [41], [42]. The overall effect size is determined to measure the effect of using DGS on students' mathematical abilities. Effect sizes have many advantages over using only tests of statistical significance. [56]. The steps involved in the meta-analysis include identifying the problem, searching for related literature, coding the studies according to certain criteria, conducting statistical analysis, and interpretations [38], [57]-[60]. In this research, this stage was also conducted.

\subsection{Study search}

Empirical data is traced from an electronic database that includes the Educational Resource Information Center (ERIC), Springer Publishing, SAGE publishing, and 
google scholar. The keywords used include "dynamic geometry software, Cabri, GeoGebra, Geo sketchpad, and mathematical abilities." Furthermore, Google Scholar and Portal Garuda were used to assess national journal articles using "dynamic geometry software, Cabri, GeoGebra, Geo sketchpad, and kemampuan matematis" as keywords. The results showed 129 studies had examined the effectiveness of DGS in learning mathematics in Indonesia between 2010 and 2020.

\subsection{Coding process and inclusion criteria}

The information derived from each study was coded using a coding sheet, an instrument used in meta-analysis to collect statistical information needed to transform effect sizes and obtain study characteristics from each identified primary study. The coding form was developed to maintain the analyzed studies' reliability, and this required filling of the coding form separately by two coders who were doctoral students with prior special training in meta-analysis. This coding considers the sample's eligibility requirements under study, i.e., the literature studied is selected from experimental studies on the impact of DGS in Indonesia over the last decade (2010-2020). Moreover, samples with no means, standard deviation, and sample size statistics were excluded. This stage provides a total of 50 research articles that meet the eligibility for analysis, and due to the use of more than one experimental or control group in several studies, 57 effect sizes are analyzed. The formula for Cohen's Cappa, denoted by Cohen $\kappa(7)$, is a powerful statistic to test inter-coder reliability [61]. The formula is:

$$
\kappa=\frac{\operatorname{Pr}(a)-\operatorname{Pr}(e)}{1-\operatorname{Pr}(e)}
$$

Where $\operatorname{Pr}$ (a) represents an actually observed agreement, and $\operatorname{Pr}$ (e) represents a coincidence agreement. A deal level of 0.85 or greater is pre-determined to be considered high. An agreement rate of 0.92 was obtained for this study. Thus, this metaanalysis is reliable. The studies included in the analysis process are presented in Appendix 1 .

\subsection{Statistical analysis}

The statistical analysis steps in this study are based on the explanation of Borenstein et al. (2009), namely:

a) Calculating the effect size of each primary study

b) Conducting heterogeneity tests and selecting the estimation model

c) Examining publication bias

d) Calculate the p-value to test the research hypothesis

Further analysis, namely answering the second to sixth questions, has been carried out because the effect size estimation uses a random-effect model [61]. Software that helps data analysis is the Comprehensive Meta-Analysis (CMA) series 3. Cohen's equation is a good estimate for the population but is biased towards studies that 
contain small samples [62]. Therefore, the Hedges equation $g$ is applied to avoid this bias while the effect size is interpreted using the classification developed by [63], which is presented in Table 1 below:

Table 1. Cohen's effect size classification

\begin{tabular}{|c|l|}
\hline Effect Size (ES) & Interpretation \\
\hline $0,00 \leq \mathrm{ES}<0,20$ & Ignored \\
\hline $0,20 \leq \mathrm{ES}<0,50$ & Small \\
\hline $0,50 \leq \mathrm{ES}<0,80$ & Moderate \\
\hline $0,80 \leq \mathrm{ES}<1,30$ & Large \\
\hline $1,30 \leq \mathrm{ES}$ & Very Large \\
\hline
\end{tabular}

The CMA program provides an effect size for each study and combined effect size for each group of study characteristics as well as homogeneity between groups known as the $\mathrm{Qb}$ value (Qbetwen), resulting in statistically heterogeneous effect sizes $\mathrm{Qb}>$ $\chi 2.95 ; \mathrm{p}<0.05$, the effect size homogeneity hypothesis is rejected [64]. This means that the study characteristic groups' effect sizes do not measure the same population parameters [38] or that there is a statistically significant difference in the average effect size for each study characteristics group [47].

\section{Results}

\subsection{Research results regarding the first question}

The first objective of this analysis was to assess the effect of the use of DGS on students' overall mathematical abilities. Therefore, on the basis of CMA-assisted calculations, the effect size and confidence interval limits were obtained and provided in Table 2.

Table 2. Study effect sizes, confidence intervals, and standard errors

\begin{tabular}{|l|c|c|c|c|}
\hline \multirow{2}{*}{\multicolumn{1}{c|}{ Author }} & \multirow{2}{*}{ Effect Size } & \multicolumn{2}{c|}{ Confidence Interval } & \multirow{2}{*}{ Standard error } \\
\cline { 3 - 4 } & & Lower limit & Upper limit & \\
\hline Abduh \& Sutarto, 2012 & 0.83 & 0.33 & 1.34 & 0.25 \\
\hline Hendriana, et al. 2019 & 1.23 & 0.74 & 1.75 & 0.25 \\
\hline Ramadani, et al. 2016 & 0.44 & -0.01 & 0.90 & 0.22 \\
\hline Risnawati, 2012 & 1.17 & 0.59 & 1.79 & 0.30 \\
\hline Sari, 2013 & 0.13 & -0.48 & 0.74 & 0.30 \\
\hline Nurhayati, 2013 & 1.75 & 1.18 & 2.38 & 0.30 \\
\hline Hartatiana, et al. 2017 & 0.70 & 0.36 & 1.04 & 0.17 \\
\hline Hartatiana, et al. a 2017 & 0.99 & 0.52 & 1.48 & 0.24 \\
\hline Hartatiana, et al. b 2017 & 0.91 & 0.41 & 1.42 & 0.25 \\
\hline Hikmah, et al. 2019 & 0.42 & -0.06 & 0.90 & 0.24 \\
\hline Saumi \& Amalia, 2017 & 1.76 & 1.06 & 2.53 & 0.36 \\
\hline Subroto, 2011 & 4.71 & 3.69 & 5.87 & 0.54 \\
\hline Syamsuduha, 2011 & 0.91 & 0.39 & 1.45 & 0.26 \\
\hline
\end{tabular}




\begin{tabular}{|c|c|c|c|c|}
\hline Nuriadin a, 2015 & 2.05 & 1.40 & 2.77 & 0.34 \\
\hline Nuriadin b, 2015 & 0.68 & 0.12 & 1.25 & 0.28 \\
\hline Priyanto, et al. a 2018 & 0.50 & 0.01 & 1.00 & 0.25 \\
\hline Priyanto et al. b 2018 & 0.29 & -0.20 & 0.78 & 0.24 \\
\hline Lexbin \& Natalia, 2011 & 0.59 & 0.10 & 1.10 & 0.25 \\
\hline Aisyah, 2015 & 1.27 & 0.72 & 1.87 & 0.28 \\
\hline Anggroratri a, 2014 & 0.32 & -0.27 & 0.93 & 0.30 \\
\hline Anggroratri b, 2014 & 0.16 & -0.45 & 0.76 & 0.30 \\
\hline Annajmi a, 2016 & 2.10 & 1.58 & 2.67 & 0.27 \\
\hline Annajmi b, 2016 & 1.02 & 0.57 & 1.50 & 0.23 \\
\hline Atikasari, et al. 2013 & 0.97 & 0.48 & 1.48 & 0.25 \\
\hline Senjayawati, et al. 2018 & 1.08 & 0.56 & 1.62 & 0.26 \\
\hline Erana, et al. 2018 & 3.09 & 2.40 & 3.86 & 0.36 \\
\hline Farihah, 2015 & 1.32 & 0.79 & 1.88 & 0.27 \\
\hline Fitra \& Sitorusn, 2019 & 0.97 & 0.38 & 1.58 & 0.30 \\
\hline Fitra \& Syahputra, 2018 & 0.79 & 0.27 & 1.32 & 0.26 \\
\hline Habinuddin, 2018 & 0.63 & 0.25 & 1.03 & 0.19 \\
\hline Haris \& Rahma, 2018 & 1.05 & 0.56 & 1.55 & 0.25 \\
\hline Jelatu et al, 2018 & 0.73 & 0.01 & 1.50 & 0.36 \\
\hline Khotimah, 2018 & 0.79 & 0.35 & 1.25 & 0.22 \\
\hline Priyono \& Hermanto, 2015 & 0.10 & -0.36 & 0.56 & 0.23 \\
\hline Ramadhani, 2017 & 0.48 & 0.03 & 0.95 & 0.23 \\
\hline Rosyid, 2018 & 2.99 & 2.30 & 3.75 & 0.36 \\
\hline Septian, 2016 & 1.96 & 1.38 & 2.59 & 0.30 \\
\hline Setyani \& Lestari, 2015 & 0.10 & -0.45 & 0.66 & 0.27 \\
\hline Siswanto, et al. 2017 & 1.61 & 1.04 & 2.21 & 0.29 \\
\hline Sumarni et al, 2017 & 5.50 & 4.49 & 6.65 & 0.54 \\
\hline Supriadi et al, 2014 & 2.36 & 1.75 & 3.03 & 0.32 \\
\hline Usman \& Halim, 2017 & 1.12 & 0.64 & 1.62 & 0.24 \\
\hline Purwasih et al, 2020 & 0.44 & -0.02 & 0.91 & 0.23 \\
\hline Kusumah et al, 2020 & 0.79 & 0.35 & 1.25 & 0.22 \\
\hline Juandi \& Priatna, 2018 & 0.18 & -0.30 & 0.68 & 0.24 \\
\hline \begin{tabular}{|l|} 
Nurhayati et al, 2020 \\
\end{tabular} & 0.76 & 0.20 & 1.36 & 0.29 \\
\hline Sutrisno et al a, 2020 & 1.33 & 0.75 & 1.94 & 0.29 \\
\hline Sutrisno et al b, 2020 & 1.14 & 0.57 & 1.75 & 0.29 \\
\hline Hamidah et al, 2020 & 0.36 & -0.17 & 0.89 & 0.26 \\
\hline Hindriyanto, et al. 2018 & 0.45 & -0.05 & 0.96 & 0.25 \\
\hline Ikhsanudin a, 2014 & 1.61 & 1.05 & 2.21 & 0.29 \\
\hline Ikhsanudin b, 2014 & 0.76 & 0.24 & 1.29 & 0.26 \\
\hline Nurhidayah, et al. 2018 & 1.96 & 1.38 & 2.59 & 0.30 \\
\hline Surya, 2015 & 0.16 & -0.28 & 0.61 & 0.22 \\
\hline Suryamiharja, 2017 & 0.73 & 0.28 & 1.20 & 0.23 \\
\hline Sya'diah, et al. 2014 & 0.54 & 0.05 & 1.03 & 0.24 \\
\hline Mayasary, et al. 2020 & 1.19 & 0.54 & 1.88 & 0.33 \\
\hline
\end{tabular}

Table 3 shows the overall effect sizes ranged between 0.10 and 5.50, with a 95\% confidence limit, while Figure 1 shows the level of the effect size of the entire study based on [63] classification. 


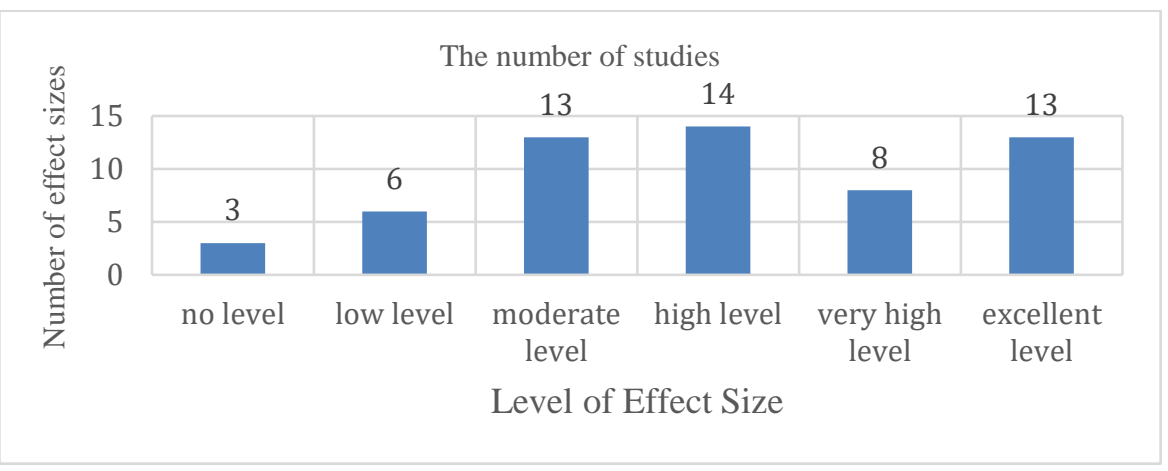

Fig. 1. Classification of effect sizes

Figure 1 shows the different effect sizes obtained from the studies conducted on using DGS in mathematics learning, while Table 3 illustrates the results of the descriptive meta-analysis according to the estimation method.

Table 3. Description of the meta-analysis results according to the estimation model

\begin{tabular}{|c|c|c|c|c|c|c|c|c|}
\hline \multirow[b]{2}{*}{ Model } & \multirow[b]{2}{*}{$\mathbf{n}$} & \multirow[b]{2}{*}{$\mathbf{Z}$} & \multirow[b]{2}{*}{$\mathbf{P}$} & \multirow[b]{2}{*}{$\mathbf{Q}$} & \multirow[b]{2}{*}{$\begin{array}{l}\text { I-squared Table value } \\
\qquad(\mathbf{p}=\mathbf{0 . 0 5})\end{array}$} & \multirow[b]{2}{*}{ Effect Size } & \multicolumn{2}{|c|}{ Confidence Interval } \\
\hline & & & & & & & $\begin{array}{l}\text { Lower } \\
\text { limit }\end{array}$ & $\begin{array}{l}\text { Upper } \\
\text { limit }\end{array}$ \\
\hline Fixed-effects & 57 & 25.96 & 0.00 & 394.93 & 85.82 & 0.92 & 0.85 & 0.90 \\
\hline Random-effects & 57 & 11.34 & 0.00 & 394.93 & 85.82 & 1.07 & 0.89 & 1.26 \\
\hline
\end{tabular}

As shown in Table 3, the mean effect size was calculated to be 0.92 , and this was classified as a high level according to [63]. The estimation method is determined through the effect size homogeneity test, which shows the Q value to be 394.93, and it is found to be more than $74.56(\mathrm{df}=56 ; \mathrm{p}=0.05)$ in table tabel $\chi 2$. This means that the effect sizes between studies differ. Therefore, the estimation model to determine the impact of using DGS on students' mathematical abilities as a whole could be evaluated using the random-effects model.

The random-effects model in Table 3 showed the lower limit was 0.89 while the upper limit was 1.26 while the average was 1.07 at a $95 \%$ confidence interval. This was classified as a very high level, according to [63]. Moreover, the significance test results gave $\mathrm{z}$ value as 11.34 and $\mathrm{p}=0.00$, indicating that the use of DGS in mathematics learning resulted in a larger effect size than conventional approaches.

The challenge in meta-analysis research is to avoid publication bias, namely the fact that statistically significant articles have a higher chance of being published and that researchers also rarely $(6 \%)$ try to publish insignificant research [65]. This tendency leads to an over-representation of significant studies, similar to the loss of studies that actually exist [38], [66], [67]. Therefore, a study funnel plot was included in determining the existence of publication bias in this study, and the result is presented in Figure 2. 


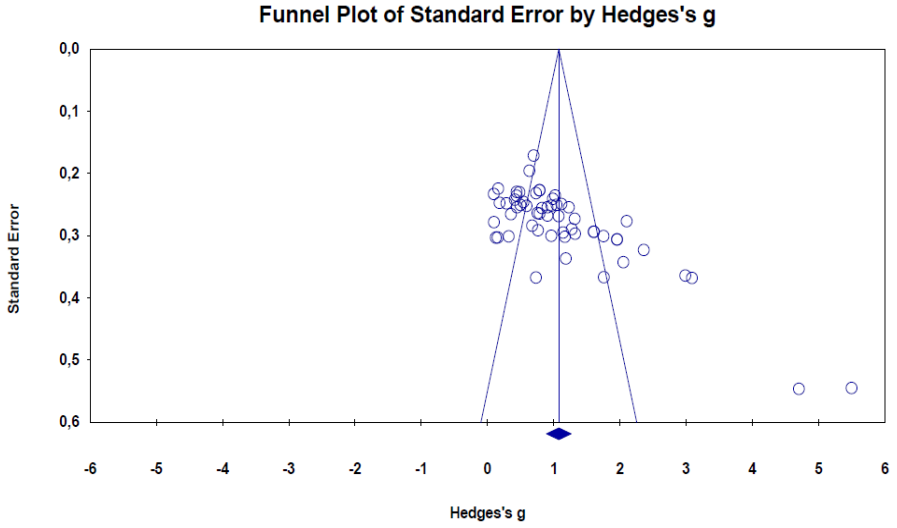

Fig. 2. Funnel plot related to the effect sizes of the studies included in the meta-analysis

Figure 2 shows that the scattered effect's size is not entirely symmetrical in the middle of the funnel plot. Therefore, Trim and Fill tests were carried out to evaluate the extent of the effects associated with publication bias in the effect sizes obtained from the meta-analysis conducted according to the random effects of the model, and the results are presented in Table 4.

Table 4. Trim and Fill test results

\begin{tabular}{|l|c|c|c|c|c|}
\hline & \multirow{2}{*}{$\begin{array}{c}\text { Studies } \\
\text { Trimmed }\end{array}$} & \multirow{2}{*}{ Point } & \multicolumn{2}{|c|}{ Confidence Interval } & Q Value \\
\cline { 4 - 6 } & & 1.07 & Lower Limit & Upper Limit & \\
\hline Observed values & & 0.89 & 1.26 & 394.93 \\
\hline Adjusted values & 0 & 1.07 & 0.89 & 1.26 & 394.93 \\
\hline
\end{tabular}

Table 4 shows there was no difference between the size of the observed and virtual effects created according to the random effect model conducted to correct the impacts of publication bias. Thus, there is no publication bias in this study

\subsection{Research results regarding the second question}

Descriptive statistics about the second question are illustrated in Table 5.

Table 5. Effect size according to a year of study

\begin{tabular}{|c|c|c|c|c|c|c|}
\hline \multirow{2}{*}{ Year } & \multirow{2}{*}{$\mathbf{N}$} & \multirow{2}{*}{ Effect Size } & \multicolumn{2}{|c|}{ \%95 Confidence Interval } & \multicolumn{2}{c|}{ Heterogeneity Test } \\
\cline { 4 - 7 } & & Lower limit & Upper limit & Qb value & $\boldsymbol{p}$ \\
\hline $2010-2012$ & 5 & 1.07 & 0.82 & 1.33 & & \\
\hline $2013-2015$ & 16 & 0.81 & 0.67 & 0.95 & 8.10 & 0.04 \\
\hline $2016-2018$ & 26 & 1.01 & 0.91 & 1.11 & & \\
\hline $2019-2020$ & 10 & 0.82 & 0.65 & 0.99 & & \\
\hline
\end{tabular}


Table 5 shows the effect sizes between study groups based on the study year varied. The statistical value of $\mathrm{Q}$ obtained from the homogeneity test was 8.10 , and since this is greater than $7.81(\mathrm{df}=3 ; \mathrm{p}=0.05)$ in table $\chi 2$, the effect size distribution has a heterogeneous structure. This, therefore, means the effect size of mathematical ability using DGS in mathematics learning between study groups differs based on the year of the study.

\subsection{Research results regarding the third question}

Descriptive statistics about the third question are presented in Table 6

Table 6. The effect size of the study according to the educational stage

\begin{tabular}{|l|c|c|c|c|c|c|}
\hline \multirow{2}{*}{$\begin{array}{c}\text { Educational } \\
\text { Stage }\end{array}$} & \multirow{2}{*}{$\mathbf{N}$} & \multirow{2}{*}{ Effect Size } & \multicolumn{2}{c|}{ \%95 Confidence Interval } & \multicolumn{2}{c|}{ Heterogeneity Test } \\
\cline { 4 - 8 } & & & Lower limit & Upper limit & Qb value & $\mathrm{p}$ \\
\hline College & 8 & 1.05 & 0.83 & 1.27 & & \\
\hline JHS & 33 & 0.95 & 0.86 & 1.04 & 7.07 & 0.02 \\
\hline SHS & 16 & 1.76 & 0.64 & 0.89 & & \\
\hline
\end{tabular}

Table 6 shows the effect sizes between study groups based on education levels also varied. The Q statistical value obtained from the homogeneity test was 7.07, and since it is greater than $5.99(\mathrm{df}=2 ; \mathrm{p}=0.05)$ in table $\chi 2$, the effect size distribution has a heterogeneous structure. This, therefore, means the effect size of mathematical ability using DGS in mathematics learning between study groups differs based on the level of research education.

\subsection{Research results regarding the fourth question}

Descriptive statistics about the fourth question are presented in Table 7

Table 7. Effect sizes of the studies according to the sample size

\begin{tabular}{|l|c|c|c|c|c|c|}
\hline \multirow{2}{*}{ Sample Size } & \multirow{2}{*}{$\mathbf{N}$} & \multirow{2}{*}{ Effect Size } & \multicolumn{2}{|c|}{ \%95 Confidence Interval } & \multicolumn{2}{|c|}{ Heterogeneity Test } \\
\cline { 4 - 5 } & & & Lower limit & Upper limit & Qb value & $\boldsymbol{p}$ \\
\hline $0-30$ & 23 & 1.09 & 0.86 & 1.11 & \multirow{2}{*}{4.81} & \multirow{2}{*}{0.04} \\
\hline 31 and over & 34 & 0.89 & 0.80 & 1.97 & & \\
\hline
\end{tabular}

Table 7 shows there was a variation in the effect sizes between study groups based on sample size. This was associated with the $\mathrm{Q}$ statistical value obtained from the homogeneity test to be 4.81 , and since this was greater than 3.81 with 1 degree of freedom and $\mathrm{p}=0.05$ in table $\chi 2$, the effect size distribution has a heterogeneous structure. This means the effect size of the mathematical ability recorded using DGS in mathematics learning between study groups differs based on the size of the research sample. 


\subsection{Research results regarding the fifth question}

Descriptive statistics about the fifth question are presented in Table 8.

Table 8. Effect sizes of the studies according to the type DGS

\begin{tabular}{|l|c|c|c|c|c|c|}
\hline \multirow{2}{*}{ DGS type } & \multirow{2}{*}{$\mathbf{N}$} & \multirow{2}{*}{ Effect Size } & \multicolumn{2}{c|}{ \%95 Confidence Interval } & \multicolumn{2}{c|}{ Heterogeneity Test } \\
\cline { 4 - 7 } & & & Lower limit & Upper limit & Qb value & $\boldsymbol{p}$ \\
\hline CABRI & 12 & 0.90 & 0.76 & 1.05 & & \\
\hline GEO SKETCHPAD & 6 & 0.73 & 0.51 & 0.94 & 6.19 & 0.10 \\
\hline GeoGebra & 31 & 0.98 & 0.89 & 1.08 & & \\
\hline WINGEOM & 8 & 0.80 & 0.62 & 0.62 & & \\
\hline
\end{tabular}

Table 8 indicates there was a variation in the effect sizes between study groups based on DGS type. This was associated with the 6.19 obtained as the statistical value of Q from the homogeneity test, and due to the fact that this is smaller than 7.81 ( $\mathrm{df}=$ $3 ; \mathrm{p}=0.05$ ) in table $\chi 2$, the effect size distribution has a homogeneous structure. Therefore, there was no difference in the effect size of mathematical ability using DGS in mathematics learning between study groups based on the type used.

\subsection{Research results regarding the sixth question}

Descriptive statistics about the sixth question are presented in Table 9.

Table 9. Effect sizes of the studies according to the student and computer ratio

\begin{tabular}{|l|c|c|c|c|c|c|}
\hline \multirow{2}{*}{$\begin{array}{c}\text { Student and } \\
\text { Computer Ratio }\end{array}$} & \multirow{2}{*}{$\mathbf{N}$} & \multirow{2}{*}{ Effect Size } & \multicolumn{2}{c|}{ \%95 Confidence Interval } & \multicolumn{2}{c|}{ Heterogeneity Test } \\
\cline { 1 - 4 } & & & Lower limit & Upper limit & Qb value & $\boldsymbol{p}$ \\
\hline Individual & 20 & 1.10 & 0.98 & 1.22 & \multirow{2}{*}{12.83} & \multirow{2}{*}{0.00} \\
\hline Group & 37 & 0.83 & 0.74 & 0.91 & & \\
\hline
\end{tabular}

Table 9 shows a variation in the effect sizes between study groups based on student and computer ratios used in learning. The statistical value of $\mathrm{Q}$ obtained from the homogeneity test was 12.83 , and since this is greater than $3.84(\mathrm{df}=1 ; \mathrm{p}=0.05)$ in table $\chi^{2}$, the effect size distribution has a heterogeneous structure. This, therefore, means there is a difference between the effect size of mathematical ability using DGS in mathematics learning for study groups differs based on the ratio of students and computers used in the process.

\section{Discussion}

This study analyzed 57 effect sizes, and according to the random-effects model, the combined effect size was found to be 1.07. This shows that the use of DGS in mathematics learning has a high positive impact compared to conventional methods. It shows the average student treated using DGS exceeded the $84 \%$ mathematical ability of those in conventional classes, which were initially equivalent. Based on the inter- 
pretation table from [68], the average students ranked 16th in the experimental group were equivalent to those ranked 6th in the control group.

This finding is in line with previous meta-analysis studies conducted by [52] to compare the effectiveness of DGS-based through the analysis of 587 primary studies and found a combined effect size of 1.02. Even though the number of studies included in this present research was ten times smaller than the sample size, very similar results were obtained, reflecting the overall trend. Another previous meta-analysis study compared the effectiveness of math software used on students' math abilities by analysing 51 primary studies, and an effect size of 1.102 was found [37]. Some other related studies showed the use of computers in learning influences students' mathematical abilities [47]-[54], [64]. Therefore, the results of this study and other related research shows using DGS in mathematics learning can improve and a very high effect on students' mathematical abilities.

The results also indicate that more study characteristics are related to effect size. The strongest relationship was found for the following variables: year of study, level of education, sample size, and student to computer ratio. The effect size does not differ based on the type of DGS used in learning.

Significant differences were observed between the study groups based on the research year as observed in the effect size value of 0.82 considered as high level found for the latest year study group, which is smaller than for the oldest year, which was 1.07 and considered very high level. This is very surprising and contradicts previous predictions that the effect size of using DGS on the mathematical abilities of latest year students is greater due to the continuous update of the software and improvement in teachers' quality. However, it is supported by previous studies that the effect size of studies in older study groups was greater than those in newer study groups [47], [49]. The higher values obtained for, the older study groups are associated with the Hawthorne effect, which occurs when students are stimulated to make greater efforts simply due to the novelty of the treatment [47]. As of 2010, the use of DGS in mathematics learning was new in Indonesia.

The results showed a strong relationship between the DGS effectiveness and education level. The effect size of the software's application in tertiary institutions and SHS was found to be greater than on JHS. This was in line with the findings of [55], which showed significant differences in effect size for different school levels but not the same with the results of [37] and [49] that there was no significant difference.

The analysis also showed a strong relationship between DGS effectiveness and sample size, as observed in the effect size variations between small (0-30), which was 1.09 , and large sample sizes ( 31 and over) with 0.89 . This means a small sample size should be considered more in teaching settings. This is in line with the findings of [37] and [53] that the effect size of the study group in small samples was greater than those in large samples. However, it is different from the results of [49], [52], [55] that study groups in small samples had smaller effect sizes. This variation, therefore, needs to be further investigated.

This meta-analysis also showed there was no significant difference in effect size based on the type of DGS used. This means every type of DGS is effective in mathematics learning, with the largest combined effect size of 0.98 was GeoGebra from 31 
studies. However, this characteristic of this study has not been extensively investigated in the previous meta-analysis.

A significant relationship was also found between the DGS effectiveness and students' ratio to the computers used. This was associated with the extraordinary difference in effect sizes for individuals (one student uses one computer), which was 1.10, and the 0.83 recorded for group implementation (one computer used by more than one student). This, therefore, means individual versions should be considered more in teaching settings. These results are in line with [47] that learning using computers individually has a larger effect size than a collective use.

\section{Conclusion}

This study was conducted by integrating the findings of the effects of using DGS on students' mathematical abilities, both as a whole and in several key study characteristics. The results of the analysis reveal that the use of DGS has a high positive impact on students' math abilities. The assessment of the DGS effectiveness based on study characteristics showed it is more effective under certain conditions. First, it was found to be very effective in sample conditions less than or equal to 30 . Second, it provides classrooms with a sufficient number of computers, allowing students to use them individually, which is recommended for a higher level of effectiveness. Third, DGS's use was recorded to be more effective in high schools and colleges than in junior high schools. Some differences in effect sizes were observed in terms of the year the studies were conducted. Most recent study groups were found to have smaller values compared to older studies. This shows the consideration of the Hawthorne effect in the mathematics teaching process. Meanwhile, different types of DGS can be used without any exception.

Even though the use of DGS was found to have a very high effect on students' mathematical abilities, the results were only based on studies with certain criteria, with some similar studies not analysed due to inadequate required statistical information. For this study's purpose, only five research characteristics were examined and they include the year the study was conducted, level of education, sample size, type of DGS, and the ratio of students to computers. Meanwhile, some others, such as the study's location, treatment duration, teacher's role as a tutor or instructor, and computer's role as an addition or a substitute for the teacher. Consequently, these conclusions do not reflect the overall effectiveness of using DGS in mathematics learning. Therefore, for further research, a detailed investigation is required to determine DGS's effectiveness using some of the characteristics that have not been investigated.

\section{Acknowledgment Results}

This research was funded by a graduate school grant (HSPS-2019) under the Universitas Pendidikan Indonesia, Bandung, Indonesia. 


\section{$7 \quad$ References}

[1] H. Bakirci, A. K. Bilgin, and A. Şimşek, "The effects of simulation technique and worksheets on formal operational stage in science and technology lessons," Procedia - Soc. Behav. Sci., vol. 15, pp. 1462-1469, 2011, https://doi.org/10.1016/j.sbspro.2011.03.311.

[2] C. S. Koong and C. Y. Wu, "The applicability of interactive item templates in varied knowledge types," Comput. Educ., vol. 56, no. 3, pp. 781-801, 2011, https://doi.org/10.10 16/j.compedu.2010.10.021.

[3] F. N. Koranteng, F. K. Sarsah, E. Kuada, and S. A. Gyamfi, "An empirical investigation into the perceived effectiveness of collaborative software for students' projects," Educ. Inf. Technol., 2019, https://doi.org/10.1007/s10639-019-10011-7.

[4] E. Tatar, T. Berrin, K. A. Ğ. Izmanli, and A. Akkaya, "The Effect of a Dynamic Software on the Success of Analytical Analysis of the Circle and Prospective Mathematics Teachers Opinions," J. Electron. Sci. Math. Educ., vol. 8, no. 1, pp. 153-177, 2014, https://doi.org/10.12973/nefmed.2014.8.1.a7 .

[5] M. Tamur, E. Sennen, and F. E. Men, Konsep Dasar Matematika Berbasis CAS dan DGS. STKIP St. Paulus Ruteng, 2018.

[6] Š. Berežný, "What Software to use in the Teaching of Mathematical Subjects?" Acta Didact. Napocensia, vol. 8, no. 1, 2015, [Online]. Available: https://files.eric.ed.gov/fulltext/ EJ1064386.pdf.

[7] M. Hohenwarter and K. Jones, "Ways of linking geometry and algebra: the case of Geogebra," in Proceedings of the British Society for Research into Learning Mathematics, 2007, vol. 3, pp. 126-131, [Online]. Available: https://eprints.soton.ac.uk/50742/1/Hohenwarter \%2526Jones_linking_geometry_and_algebra_Geogebra_2007.pdf .

[8] C. Kustandi, D. N. Fadhillah, R. Situmorang, D. S. Prawiradilaga, and S. Hartati, "VR use in online learning for higher education in Indonesia," Int. J. Interact. Mob. Technol., vol. 14, no. 1, pp. 31-47, 2020, https://doi.org/10.3991/ijim.v14i01.11337.

[9] G. M. Gonzalez and M. A. Birch, "Evaluating the Instructional Efficacy of ComputerMediated Interactive Multimedia: Comparing Three Elementary Statistics Tutorial Modules," Educ. Comput. Res., vol. 22, no. 4, pp. 411-436, 2018, https://doi.org/10.2190/x8 pq-k0gq-t2dr-xy1a.

[10] D. Juandi and N. Priatna, "Discovery learning model with geogebra assisted for improvement mathematical visual thinking ability," J. Phys. Conf. Ser., vol. 1013, no. 1, 2018, https://doi.org/10.1088/1742-6596/1013/1/012209.

[11] S. Papadakis, M. Kalogiannakis, and N. Zaranis, "Improving Mathematics Teaching in Kindergarten with Realistic Mathematical Education," Early Childhood Education Journal, vol. 45, no. 3, pp. 369-378, 2016, https://doi.org/10.1007/s10643-015-0768-4.

[12] T. Koparan, "The effect of dynamic geometry software on prospective teachers' achievement about locus problems,” Turkish Online J. Educ. Technol., no. 2, pp. 587-591, 2015.

[13] Sudirman, Mellawaty, R. P. Yaniwati, and R. Indrawan, "Integrating local wisdom forms in augmented reality application: Impact attitudes, motivations and understanding of geometry of pre-service mathematics teachers', Int. J. Interact. Mob. Technol., vol. 14, no. 11, pp. 91-106, 2020, https://doi.org/10.3991/ijim.v14i11.12183.

[14] A. Svela, J. Nouri, O. Viberg, and L. Zhang, "A systematic review of tablet technology in mathematics education,” Int. J. Interact. Mob. Technol., vol. 13, no. 8, pp. 139-158, 2019, https://doi.org/10.3991/ijim.v13i08.10795.

[15] S. J. Papadakis, N. Zaranis, and M. Kalogiannakis, "Comparing Tablets and PCs in teaching Mathematics: An attempt to improve Mathematics Competence in Early Childhood 
Education,” Presch. Prim. Educ., vol. 4, no. 2, pp. 241-253., 2016, https://doi.org/10.126 81/ppej.8779.

[16] S. Papadakis, M. Kalogiannakis, and N. Zaranis, "The effectiveness of computer and tablet assisted intervention in early childhood students " understanding of numbers. An empirical study conducted in Greece,” Educ Inf Technol, vol. 23, pp. 1849-1871, 2018, https://doi. org/10.1007/s10639-018-9693-7.

[17] A. Oldknow, "Dynamic Geometry Software - A Powerful Tool for Teaching Mathematics, not just Geometry!" 3rd Int. Conf. Technol. Math. Teach., no. February, pp. 1-15, 2015, [Online]. Available: https://www.researchgate.net/publication/2812249_Dynamic_Geomet ry Software - a powerful tool for teaching mathematics not just geometry. https://do i.org/10.1093/teamat/14.2.86

[18] A. S. Drigas and M. A. Pappas, "A review of mobile learning applications for mathematics,” Int. J. Interact. Mob. Technol., vol. 9, no. 3, pp. 18-23, 2015, https://doi.org/10.3991/ ijim.v9i3.4420.

[19] F. M. Adelabu and M. Makgato, "Attitudes of male and female students to dynamic geometry computer software for learning mathematics," World Trans. Eng. Technol. Educ., vol. 17, no. 3, pp. 314-319, 2019, [Online]. Available: http://www.wiete.com.au/journals/ WTE\&TE/Pages/Vol.17No.3(2019)/17-Adelabu-F.pdf .

[20] A. Baki, T. Kosa, and B. Guven, "A comparative study of the effects of using dynamic geometry software and physical manipulatives on the spatial visualisation skills of preservice mathematics teachers," Br. J. Educ. Technol., vol. 42, no. 2, pp. 291-310, 2011, https://doi.org/10.1111/j.1467-8535.2009.01012.x

[21] S. P. Gordon and F. S. Gordon, "Visualizing and Understanding Hypothesis Testing Using Dynamic Software," Primus, vol. 30, no. 2, pp. 172-190, 2020, https://doi.org/10.1080/10 $\underline{511970.2018 .1534295 .}$.

[22] K. M. Kim and R. Md-Ali, "Geogebra: Towards realizing 21 st century learning in mathematics education,” Malaysian J. Learn. Instr., no. Specialissue, pp. 93-115, 2017. https:// doi.org/10.32890/mjli.2017.7799

[23] K. ouml sa Temel, "Effects of using dynamic mathematics software on pre-service mathematics teacher's spatial visualization skills: The case of spatial analytic geometry," Educ. Res. Rev., vol. 11, no. 7, pp. 449-458, 2016, https://doi.org/10.5897/err2016.2686.

[24] A. K. Knapp, J. E. Barrett, and C. J. Moore, "Prompting Teacher Geometric Reasoning through Coaching in a Dynamic Geometry Software Context," Sch. Sci. Math., vol. 116, no. 6, pp. 326-337, 2016, https://doi.org/10.1111/ssm.12184.

[25] B. Özçakir and E. ÇakiroĞlu, "Effects of Dynamic Geometry Activities on Seventh Graders 'Learning on Area of Quadrilaterals," Int. J. Math. Teach. Learn., vol. 20, no. 2, pp. 257-271, 2019.

[26] Y. S. Kusumah, D. Kustiawati, and T. Herman, "The Effect of GeoGebra in ThreeDimensional Geometry Learning on Students' Mathematical Communication Ability," Int. J. Instr., vol. 13, no. 2, pp. 895-908, 2020, https://doi.org/10.29333/iji.2020.13260a.

[27] N. A. Batubara, "the Effect of Using Cabri 3Dv2Plus Software with Cooperative Interaction Setting Learning Model on Students' Mathematical Understanding in Transformation Materials,” Int. J. Educ. Best Pract., vol. 3, no. 1, p. 50, 2019, https://doi.org/10.31258/ijeb p.v3n1.p50-61.

[28] H. Hartatiana, D. Darhim, and E. Nurlaelah, "Improving Junior High School Students' Spatial Reasoning Ability Through Model Eliciting Activities with Cabri 3D," Int. Educ. Stud., vol. 11, no. 1, p. 148, 2017, https://doi.org/10.5539/ies.v11n1p148.

[29] A. Nurwijayanti, B. Budiyono, and L. Fitriana, "The Use of Interactive Media Ispring Suite 8 Supported by Google SketchUp to Improve Students' Geometry Skills Based on 
Hoffer's Theory," J. Phys. Conf. Ser., vol. 1008, no. 1, 2018, https://doi.org/10.1088/17426596/1008/1/012075.

[30] T. Subroto, "the Use of Cabri 3D Software as Virtual Manipulation Tool in 3-Dimension Geometry Learning to Improve Junior High School Students' Spatial Ability,” Int. Semin. Fourth Natl. Conf. Math. Educ., no. July, pp. 609-618, 2011.

[31] N. Supriadi, Y. S. Kusumah, J. Sabandar, and J. D. Afgani, "Developing High-Order Mathematical Thinking Competency on Hi gh School Students ' Through Geo GebraAssisted Blended Learning,” Math. Theory Model., vol. 4, no. 6, pp. 57-66, 2014, [Online]. Available: https://www.iiste.org/Journals/index.php/MTM/article/view/13109 .

[32] Z. Nuraeni and A. Rosyid, "Pengaruh Model Pembelajaran Index Card Match (ICM) dengan Problem Posing Berbantuan Software MATLAB terhadap Kemampuan Pemecahan Masalah,” J. Elem., vol. 5, no. 1, p. 12, 2019, https://doi.org/10.29408/jel.v5i1.710.

[33] S. Priyono and R. Hermanto, "Peningkatan kemampuan representasi matematik peserta didik dengan menggunakan model problem-based learning (PBL) berbantuan media software Geogebra," J. Penelit. Pendidik. dan Pengajaran Mat., vol. 1, no. 1, pp. 55-64, 2015. https://doi.org/10.35194/jp.v8i1.438

[34] N. Hamidah, I. N. Afidah, L. W. Setyowati, S. Sutini, and J. Junaedi, "Pengaruh Media Pembelajaran Geogebra Pada Materi Fungsi Kuadrat Terhadap Motivasi dan Hasil Belajar Peserta Didik," J. Educ. Learn. Math. Res., vol. 1, no. 1, pp. 15-24, 2020, https://doi.org/ 10.37303/jelmar.v1i1.2.

[35] E. Surya, "Pembelajaran Matematika Smp Berbasis Budaya Melayu dan Software Wingeom [Junior High School Mathematics Learning Based on Malay Culture and Wingeom Software]," Proc. Semirata2015 F. MIPA BKS-PTN Bara, Univ. Tanjungpura Pontianak Indones., pp. 138-150, 2015, [Online]. Available: http://jurnal.untan.ac.id/index.php/semi rata2015/article/view/14057/13269. https://doi.org/10.24114/jpmi.v1i1.8920

[36] S. Higgins and M. Katsipataki, "Evidence from meta-analysis about parental involvement in education which supports their children's learning," J. Child. Serv., vol. 10, no. 3, pp. 280-290, 2015, https://doi.org/10.1108/jcs-02-2015-0009.

[37] M. Tamur, D. Juandi, and Y. S. Kusumah, "The Effectiveness of the Application of Mathematical Software in Indonesia: A Meta-Analysis Study,” Int. J. Instr., vol. 13, no. 4, pp. 867-884, 2020, https://doi.org/10.29333/iji.2020.13453a.

[38] M. Borenstein, L. V Hedges, J. P. T. Higgins, and H. R. Rothstein, Introduction to MetaAnalysis, no. January. A John Wiley and Sons, Ltd., Publication, 2009.

[39] J. J. Randolph, "A Guide to Writing the Dissertation Literature Review in Software Engineering," Pract. Assessment, Res. Eval., vol. 14, no. 13, pp. 1-13, 2009, [Online]. Available: https://pareonline.net/getvn.asp?v=14\&n=13 .

[40] A. P. Siddaway, A. M. Wood, and L. V. Hedges, "How to Do a Systematic Review: A Best Practice Guide for Conducting and Reporting Narrative Reviews, Meta-Analyses, and Meta-Syntheses,” Annu. Rev. Psychol., vol. 70, no. 1, pp. 747-770, 2019, https://doi.org/ 10.1146/annurev-psych-010418-102803.

[41] T. J. Cleophas and A. H. Zwinderman, Modern Meta-Analysis. 2017.

[42] G. Schwarzer, J. R. Carpenter, and G. Rücker, Meta-Analysis with R. Cham Heidelberg New York Dordrecht London: Springer International Publishing Switzerland, 2015.

[43] L. B. Shelby and J. Vaske, "Understanding meta-analysis: A review of the methodological literature," Leis. Sci., vol. 30, no. 2, pp. 96-110, 2008, https://doi.org/ $10.1080 / 01490400701881366$.

[44] M. Tamur and D. Juandi, "Effectiveness of Constructivism Based Learning Models Against Students Mathematical Creative Thinking Abilities in Indonesia; A Meta-Analysis 
Study," in Mathematics, Science, and Computer Science Education International Seminar, MSCEIS 2019, 2020, pp. 1-8, https://doi.org/10.4108/eai.12-10-2019.2296507.

[45] F. L. Schmidt and J. E. Hunter, Methods of Meta-Analysis: Correcting Error and Bias in Research Findings, Third. 55 City Road, London: 55 City Road, London: SAGE Publications, Ltd, 2015.

[46] M. Franzen, "Meta-analysis," in Encyclopedia of Personality and Individual Differences, H. V. Zeigler and T. Shackelford, Eds. Springer, Cham, 2020, p. 5925.

[47] S. Bayraktar, "A meta-analysis of the effectiveness of computer-assisted instruction in science education," J. Res. Technol. Educ., vol. 34, no. 2, pp. 173-188, 2001, https://doi.org/ 10.1080/15391523.2001.10782344.

[48] S. Berney and M. Bétrancourt, "Does animation enhance learning? A meta-analysis," Comput. Educ., vol. 101, pp. 150-167, 2016, https://doi.org/10.1016/j.compedu.2016.06.0 $\underline{05}$.

[49] A. C. K. Cheung and R. E. Slavin, "The effectiveness of educational technology applications for enhancing mathematics achievement in K-12 classrooms: A meta-analysis," Educ. Res. Rev., vol. 9, no. 2013, pp. 88-113, 2013, https://doi.org/10.1016/j.edurev.2013. $\underline{01.001 .}$.

[50] K. Higgins, J. Huscroft-D’Angelo, and L. Crawford, "Effects of Technology in Mathematics on Achievement, Motivation, and Attitude: A Meta-Analysis," J. Educ. Comput. Res., vol. 57, no. 2, pp. 283-319, 2017, https://doi.org/10.1177/0735633117748416.

[51] R. K. Kaushal and S. N. Panda, "A meta-analysis on effective conditions to offer animation-based teaching style," Malaysian J. Learn. Instr., vol. 16, no. 1, pp. 129-153, 2019.

[52] S. Turgut and Ö. D. Temur, "The effect of game-assisted mathematics education on academic achievement in Turkey: A meta-analysis study," Int. Electron. J. Elem. Educ., vol. 10, no. 2, pp. 195-206, 2017, https://doi.org/10.26822/iejee.2017236115.

[53] İ. G. Turgut and S. Turgut, "The effects of visualization on mathematics achievement in reference to thesis studies conducted in Turkey: A meta-analysis," Univers. J. Educ. Res., vol. 6, no. 5, pp. 1094-1106, 2018, https://doi.org/10.13189/ujer.2018.060531.

[54] M. Yesilyurt, M. Dogan, and S. Acar, "The Meta-Analysis of the Effect of Computer Aided Instruction on Student Attitudes in Science and Mathematics," J. Prim. Educ., vol. 1, no. 2, pp. 57-69, 2019.

[55] K. K. Chan and S. W. Leung, "Dynamic geometry software improves mathematical achievement: Systematic review and meta-analysis," J. Educ. Comput. Res., vol. 51, no. 3, pp. 311-325, 2014, https://doi.org/10.2190/ec.51.3.c.

[56] P. D. Ellis, "Effect sizes and the interpretation of research results in international business,” J. Int. Bus. Stud., vol. 41, no. 9, pp. 1581-1588, 2010, https://doi.org/10.1057/jibs. 2010.39.

[57] H. Cooper, L. V Hedges, and J. C. Valentine, MICROBIOLOGY HANDBOOK Edited by, no. January. 2009.

[58] T. D. Pigott, Advances in Meta-Analysis. Springer New York Dordrecht Heidelberg London, 2012.

[59] N. Susanti, D. Juandi, and M. Tamur, "The Effect of Problem-Based Learning ( PBL ) Model On Mathematical Communication Skills of Junior High School Students - A MetaAnalysis Study," JTAM (Jurnal Teor. dan Apl. Mat., vol. 4, no. 2, pp. 145-154, 2020. https://doi.org/10.31764/jtam.v4i2.2481

[60] M. Tamur, D. Juandi, and A. M. G. Adem, "Realistic Mathematics Education in Indonesia and Recommendations for Future Implementation: A Meta-Analysis Study," J. Teor. dan Apl. Mat., vol. 4, no. 1, pp. 17-27, 2020, https://doi.org/10.31764/jtam.v4i1.1786. 
[61] M. L. McHugh, "Lessons in biostatistics interrater reliability: the kappa statistic," Biochem. Medica, vol. 22, no. 3, pp. 276-282, 2012, https://doi.org/10.11613/bm.2012.031.

[62] M. Harwell, "Growth in the Amount of Literature Reviewed in a Meta-Analysis and Reviewer Resources.," Mid-Western Educ. Res., vol. 32, no. 1, pp. 31-47, 2020.

[63] J. Cohen, Statistical power analysis for the behavioral sciences, vol. 111, no. 479. 1988.

[64] S. Demir and G. Başol, "Effectiveness of computer-assisted mathematics education (CAME) over academic achievement: A meta-analysis study," Kuram ve Uygulamada Egit. Bilim., vol. 14, no. 5, pp. 2026-2035, 2014, https://doi.org/10.12738/estp.2014.5. $\underline{2311}$.

[65] H. M. Cooper, Research Synthesis and Meta-Analysis: A Step-by-Step Approach, Fifth. Los Angeles: SAGE Publications, 2017.

[66] C. J. Ferguson and M. Heene, "A Vast Graveyard of Undead Theories: Publication Bias and Psychological Science's Aversion to the Null," Perspect. Psychol. Sci., vol. 7, no. 6, pp. 555-561, 2012, https://doi.org/10.1177/1745691612459059

[67] S. Park and S. Hong, "The empirical review of meta-analysis published in Korea," Asia Pacific Educ. Rev., vol. 17, no. 2, pp. 313-324, 2016, https://doi.org/10.1007/s12564-0169433-X

[68] R. Coe, "It's the Effect Size, Stupid," Educational Research, no. September. pp. 1-18, 2002.

\section{Authors}

Dadang Juandi is an associate professor at the department of mathematics, Universitas Pendidikan Indonesia (UPI). As well as teaching the undergraduate, postgraduate and doctoral programs of UPI mathematics education, currently, he has an additional assignment as the head of the mathematics department in charge of undergraduate, postgraduate, and doctoral education study programs and the S1 pure mathematics study program. expertise in applied mathematics, statistics, and currently, focus on meta-analysis research studies.

Yaya S Kusumah is a professor in the mathematics department, University of Education Indonesia (UPI). Currently as director of the UPI graduate program (yayaskusumah@yahoo.com).

Maximus Tamur is a doctoral student in mathematics education at the University of Pendidikan Indonesia. He is also a lecturer in the mathematics education study program of the Universitas Katolik Indonesia, Santu Paulus Ruteng, and the vicechairman of the Indonesian Mathematics Educators Association (IMES) for the Province of East Nusa Tenggara Indonesia (email: maximustamur@unikastpaulus.ac.id)

Krisna S. Perbowo is a mathematics education doctoral student at Warwick, United Kingdom. (email: k.perbowo@warwick.ac.uk)

Muhammad Daut Siagian is a mathematics education doctoral student at the mathematics education university. He is a lecturer in the mathematics education study program of the Islamic University of North Sumatra, Medan, Indonesia (email: mds iagian@fkip.uisu.ac.id)

Rini Sulastri is a mathematics education doctoral student at the mathematics education university. He is also a lecturer in the mathematics education study program, 
Serambi Mekkah University, Aceh, Indonesia (email: rini.sulastri@serambimekkah.a c.id)

Habibi R. P. Negara is a doctoral student in mathematics education at the mathematics education university. He is also a lecturer in the mathematics education study program of the Mataram State Islamic University, Mataram, Indonesia (email: habibiperwira@uinmataram.ac.id)

Article submitted 2020-09-25. Resubmitted 2020-10-19. Final acceptance 2020-10-21. Final version published as submitted by the authors.

\section{Appendix A: List of the Studies Included}

\begin{tabular}{|c|c|c|}
\hline Author & Year & Title of the Study \\
\hline Toto Subroto & 2011 & $\begin{array}{l}\text { The Use of Cabri 3D Software As Virtual Manipulation Tool in 3- } \\
\text { Dimension Geometry Learning To Improve Junior High School } \\
\text { Students' Spatial Ability }\end{array}$ \\
\hline Dodi Syamsuduha & 2011 & $\begin{array}{l}\text { The Effect of Sketchpad's Geometric Assisted Cooperative Learning } \\
\text { Towards Increased Critical Thinking Ability }\end{array}$ \\
\hline $\begin{array}{l}\text { Marchasan Lexbin \& } \\
\text { Stevi Natalia }\end{array}$ & 2011 & $\begin{array}{l}\text { Improvement of Geometric Comprehension Ability of Junior High } \\
\text { School Students through a Realistic Mathematical Approach Aided by } \\
\text { Sketchpad Geometer's Software }\end{array}$ \\
\hline $\begin{array}{l}\text { M. F. Abduh, Kartono, } \\
\& \text { Hery Sutarto }\end{array}$ & 2012 & $\begin{array}{l}\text { The Effectiveness of Tapps Learning Model Assisted by Facebook } \\
\text { Learning and Cabri on Achieving Problem Solving Capabilities }\end{array}$ \\
\hline Risnawati & 2012 & $\begin{array}{l}\text { The Effect of Learning Using Inductive-Deductive Approaches Assisted } \\
\text { by the Cabri Geometry Program Against the Improvement of Students' } \\
\text { Mathematical Representation Ability }\end{array}$ \\
\hline Diah Prawitha Sari & 2013 & $\begin{array}{l}\text { Improving Students' Critical Mathematical Thinking Ability and Self } \\
\text { Regulation Through Utilization of the Cabri Geometry II Program in the } \\
\text { Tutorial Learning Model }\end{array}$ \\
\hline Nurhayati & 2013 & $\begin{array}{l}\text { Effect of Application of Constructivism Approach with Cooperative } \\
\text { Learning Model Assisted by 3D Cabri Program on Reasoning Ability } \\
\text { and Mathematical Connection of High School Students in Tasikmalaya } \\
\text { City }\end{array}$ \\
\hline $\begin{array}{l}\text { Gias Atikasari \& Ary } \\
\text { Woro Kurniasih }\end{array}$ & 2013 & $\begin{array}{l}\text { The Effectiveness of Cooperative Learning Model with Geogebra } \\
\text { Assisted TTW Strategy on Mathematical Creative Thinking Ability of } \\
\text { Class VII Students in Triangle Material }\end{array}$ \\
\hline $\begin{array}{l}\text { Astin Stasia } \\
\text { Anggroratri }\end{array}$ & 2014 & $\begin{array}{l}\text { The Effectiveness of Geogebra Assisted Mathematics Learning with a } \\
\text { Laboratory Approach compared to the Classical Approach for } \\
\text { Stationary Values and Drawing Curves in Class XI High School }\end{array}$ \\
\hline $\begin{array}{l}\text { Nanang Supriadi, Yaya } \\
\text { S. Kusumah, Jozua } \\
\text { Sabandar, \& Jarnawi D. } \\
\text { Afgani }\end{array}$ & 2014 & $\begin{array}{l}\text { Developing High-Order Mathematical Thinking Competency on Hi gh } \\
\text { School Students ' Through Geo Gebra-Assisted Blended Learning }\end{array}$ \\
\hline Ikhsanudin & 2014 & $\begin{array}{l}\text { The Effect of Use of Wingeom's Assisted Cooperative Learning Type } \\
\text { on the Geometry Problem-Solving Capabilities of High School Students }\end{array}$ \\
\hline $\begin{array}{l}\text { Halimah Sya'diah, \& } \\
\text { Prahesti Tirta Safitri }\end{array}$ & 2014 & $\begin{array}{l}\text { The Effect of Quantum Software Assisted by Wingeom's Software on } \\
\text { Students' Mathematical Reasoning Abilities }\end{array}$ \\
\hline Ishaq Nuriadin & 2015 & $\begin{array}{l}\text { Contextual Learning Assisted by Geometer'S Sketchpad Program in } \\
\text { Improving Mathematical Communication and Communication } \\
\text { Capabilities of Junior High School Students }\end{array}$ \\
\hline Nida Aisyah & 2015 & $\begin{array}{l}\text { The influence of the problem based learning model assisted by geogebra } \\
\text { software on the ability to solve mathematical problems }\end{array}$ \\
\hline
\end{tabular}




\begin{tabular}{|c|c|c|}
\hline Umi Farihah & 2015 & $\begin{array}{l}\text { The Effect of Geogebra Interactive Program on Motivation and Student } \\
\text { Learning Outcomes on the Material of Straight Line Equation Graphs }\end{array}$ \\
\hline $\begin{array}{l}\text { Setio Priyono \& Redi } \\
\text { Hermanto }\end{array}$ & 2015 & $\begin{array}{l}\text { Improving students' mathematical representation ability by using } \\
\text { problem-based learning (PBL) models assisted by Geogebra software } \\
\text { media }\end{array}$ \\
\hline $\begin{array}{l}\text { Nanik Setyani, } \\
\text { Himmawati Puji Lestari }\end{array}$ & 2015 & $\begin{array}{l}\text { The Effectiveness of Mathematics Learning Using Geogebra Assisted } \\
\text { CPS (Creative Problem Solving) Model in terms of Learning } \\
\text { Achievement and Creativity of Class VIII Students of SMP PGRI } \\
\text { Tegalsari Purworejo Regency }\end{array}$ \\
\hline Edi Surya & 2015 & $\begin{array}{l}\text { Junior High School Mathematics Learning Based on Malay Culture and } \\
\text { Wingeom Software }\end{array}$ \\
\hline $\begin{array}{l}\text { Iqbal Ramadani, } \\
\text { Zulkarnain, \& Sehatta } \\
\text { Saragih }\end{array}$ & 2016 & $\begin{array}{l}\text { The Effect of Van Hiele Learning Model Assisted 3D Cabri Software on } \\
\text { Mathematics Learning Outcomes of Mainstay Class Its Mtsn Students } \\
\text { The Effect of Van Hiele Learning Model Assisted 3D Cabri Software } \\
\text { Against Learning Outcomes }\end{array}$ \\
\hline Annajmi & 2016 & $\begin{array}{l}\text { The Effect of Van Hiele Learning Model Assisted 3D Cabri Software on } \\
\text { Mathematics Learning Outcomes of Mainstay Class Its Mtsn Students } \\
\text { The Effect of Van Hiele Learning Model Assisted 3D Cabri Software } \\
\text { Against Learning Outcomes }\end{array}$ \\
\hline Ari Septian & 2016 & $\begin{array}{l}\text { Application of Geogebra to Improve Mathematical Problem Solving } \\
\text { Ability of Students in the Mathematics Education Study Program at } \\
\text { Suryakancana University }\end{array}$ \\
\hline $\begin{array}{l}\text { Hartatiana, Darhim, \& } \\
\text { Nurlaelah }\end{array}$ & 2017 & $\begin{array}{l}\text { Improving Junior High School Students' Spatial Reasoning Ability } \\
\text { Through Model Eliciting Activities with Cabri 3D }\end{array}$ \\
\hline $\begin{array}{l}\text { Hartatiana, Darhim, \& } \\
\text { Nurlaelah }\end{array}$ & 2017 & $\begin{array}{l}\text { Student's Spatial Reasoning through Model Eliciting Activities with } \\
\text { Cabri 3D }\end{array}$ \\
\hline $\begin{array}{l}\text { Fazrina Saumi \& Rizki } \\
\text { Amalia }\end{array}$ & 2017 & $\begin{array}{l}\text { Application Of Brain Based Learning ( BBL ) Models Based On } \\
\text { Saintific Approach With 3D Cabries In Geometry Material To Increase } \\
\text { The Ability Of Mathematics Communications For Students Of SMAN } 1 \\
\text { Karang Baru }\end{array}$ \\
\hline Ramadhani & 2017 & $\begin{array}{l}\text { Difference Between Increasing Mathematical Self Efficacy Between } \\
\text { Students Who Get Geogebra Assisted Guided Learning Learning } \\
\text { Without Geogebra Assisted At SMPN 22 Medan }\end{array}$ \\
\hline $\begin{array}{l}\text { Rizki Dwi Siswanto \& } \\
\text { Yaya S Kusumah }\end{array}$ & 2017 & $\begin{array}{l}\text { Improvement of Spatial Geometry Ability in Junior High School } \\
\text { Students through Guided Inquiry Learning Assisted by Geogebra }\end{array}$ \\
\hline $\begin{array}{l}\text { Sumarni, Anggar T. } \\
\text { Pratitno, \& Mita } \\
\text { Nurpalah }\end{array}$ & 2017 & $\begin{array}{l}\text { Development of Economic Mathematics Teaching Materials Based on } \\
\text { Learning Cycles Assisted by Geogebra Software to Improve Student } \\
\text { Learning Outcomes }\end{array}$ \\
\hline $\begin{array}{l}\text { Muhammad Rizal } \\
\text { Usman \& Nur } \\
\text { Humairah Halim }\end{array}$ & 2017 & $\begin{array}{l}\text { Improving the Mathematical Creative Thinking Ability of High School } \\
\text { Students Through Inquiry Learning Assisted by Geogebra Software at } \\
\text { the Subject of Linear Programs }\end{array}$ \\
\hline $\begin{array}{l}\text { Bagja Nugraha } \\
\text { Suryamiharja }\end{array}$ & 2017 & $\begin{array}{l}\text { The Effect of Application of Learning Model of 3D Wingeom Software } \\
\text { Assisted Learning Against Improvement of Students' Mathematical } \\
\text { Concepts Understanding }\end{array}$ \\
\hline $\begin{array}{l}\text { Budi H. Priyanto, } \\
\text { Abduloh, \& } \\
\text { Mokhammad R. } \\
\text { Yudhanegara }\end{array}$ & 2018 & $\begin{array}{l}\text { The Role of Teaching Material Based on Van Hiele Theory on Students' } \\
\text { Mathematical Representation Ability }\end{array}$ \\
\hline $\begin{array}{l}\text { Eka Senjayawati \& } \\
\text { Martin Bernard }\end{array}$ & 2018 & $\begin{array}{l}\text { Application of Search Solve Create Share Model to Develop } \\
\text { Mathematical Reasoning Abilities Using Geogebra Software } 4.4\end{array}$ \\
\hline $\begin{array}{l}\text { Erana, Rifqi Hidayat, \& } \\
\text { Desy Lusiyana }\end{array}$ & 2018 & $\begin{array}{l}\text { Implementation of Geogebra Software Version 4.4 Learning Cycle } \\
\text { Learning Model in an Effort to Improve Mathematical Concepts and } \\
\text { Mathematical Disposition of Middle School Students }\end{array}$ \\
\hline $\begin{array}{l}\text { Awaluddin Fitra \& } \\
\text { Muhammad Romi }\end{array}$ & 2018 & $\begin{array}{l}\text { The Effect of Geogebra on Student Learning Outcomes in SPLDV } \\
\text { Material in Class VIII of Kemala Bhayangkari } 1 \text { Medan Middle School }\end{array}$ \\
\hline
\end{tabular}


Paper-The Effectiveness of Dynamic Geometry Software Applications in Learning Mathematics: ..

\begin{tabular}{|c|c|c|}
\hline Syahputra & & \\
\hline Endang Habinuddin & 2018 & $\begin{array}{l}\text { Ability Improvement In Understanding Derivative Calculus Using } \\
\text { Geogebra }\end{array}$ \\
\hline $\begin{array}{l}\text { Abd Haris \& Arif } \\
\text { Rahma }\end{array}$ & 2018 & $\begin{array}{l}\text { Student Spatial Ability Through Problem Based Learning With } \\
\text { Geogebra Software }\end{array}$ \\
\hline $\begin{array}{l}\text { Silfanus Jelatu, } \\
\text { Sariyasa, \& I Made } \\
\text { Ardana }\end{array}$ & 2018 & $\begin{array}{l}\text { Effect of GeoGebra-aided REACT strategy on understanding of } \\
\text { geometry concepts }\end{array}$ \\
\hline Khotimah & 2018 & $\begin{array}{l}\text { Improving Mathematical Literacy Skills Using Metacognitive Guidance } \\
\text { Approach Assisted by Geogebra }\end{array}$ \\
\hline $\begin{array}{l}\text { Abdul Rosyid \& Uba } \\
\text { Umbara }\end{array}$ & 2018 & $\begin{array}{l}\text { Implementation of the Missouri Mathematics Project Learning Model } \\
\text { Assisted by GeoGebra to Improve Mathematical Communication Skills } \\
\text { of Middle School Students }\end{array}$ \\
\hline $\begin{array}{l}\text { Dadang Juandi \& } \\
\text { Nanang Priatna }\end{array}$ & 2018 & $\begin{array}{l}\text { Discovery learning model with geogebra assisted for improvement } \\
\text { mathematical visual thinking ability }\end{array}$ \\
\hline $\begin{array}{l}\text { Yunio Hindriyanto \& } \\
\text { Metya Dwi Kurniasih }\end{array}$ & 2018 & $\begin{array}{l}\text { The Influence of Generative Learning Model Assisted with Wingeom } \\
\text { Software to Student 's Mathematical Learning Outcomes }\end{array}$ \\
\hline $\begin{array}{l}\text { Fadillah Nurhidayah, } \\
\text { Ervin Azhar, \& Hella } \\
\text { Jusra }\end{array}$ & 2018 & $\begin{array}{l}\text { The Effect of Jigsaw Cooperative Learning Model Assisted by } \\
\text { Wingeom Software on Mathematics Learning Outcomes of Students in } \\
\text { Negeri Negeri } 163 \text { Jakarta }\end{array}$ \\
\hline $\begin{array}{l}\text { Benny Hendriana, Ishaq } \\
\text { Nuriadin, \& Listya } \\
\text { Rachmaeni }\end{array}$ & 2019 & $\begin{array}{l}\text { The Influence Of Brain-Based Learning Model With Cabri 3d On } \\
\text { Student 'S Ability Of Spatial Mathematics }\end{array}$ \\
\hline $\begin{array}{l}\text { Rezkiyana Hikmah, Sri } \\
\text { Rezeki, \& Bayu Jaya } \\
\text { Tama }\end{array}$ & 2019 & $\begin{array}{l}\text { Use of 3D Cabri to Increase Students' Mathematical Representation } \\
\text { Ability }\end{array}$ \\
\hline $\begin{array}{l}\text { Awaludin Fitra \& } \\
\text { Martua Sitorus }\end{array}$ & 2019 & $\begin{array}{l}\text { Effect of Geogebra Application Assisted Learning on Student Learning } \\
\text { Outcomes in Class VIII Junior High School Kemala Bhayangkari } 1 \\
\text { Medan }\end{array}$ \\
\hline $\begin{array}{l}\text { Ratni Purwasih, Ratna } \\
\text { Sariningsih, \& Indah } \\
\text { Puspita Sari }\end{array}$ & 2020 & $\begin{array}{l}\text { Self Efficacy of Students' High Order Thinking Mathematics Ability } \\
\text { Through Geogebra Softwere Assisted Learning }\end{array}$ \\
\hline $\begin{array}{l}\text { Yaya S. Kusumah, } \\
\text { Dedek Kustiawati, \& } \\
\text { Tatang Herman }\end{array}$ & 2020 & $\begin{array}{l}\text { The Effect of GeoGebra in Three-Dimensional Geometry Learning on } \\
\text { Students' Mathematical Communication Ability }\end{array}$ \\
\hline $\begin{array}{l}\text { Yanti Nurhayati, Nur } \\
\text { Eva Zakiah, \& Asep } \\
\text { Amam }\end{array}$ & 2020 & $\begin{array}{l}\text { Integration of contextual teaching learning (CTL) with geogebra: can it } \\
\text { improve students' mathematical connection skills? }\end{array}$ \\
\hline $\begin{array}{l}\text { Sutrisno, Nita } \\
\text { Zuliyawati, Rina Dwi } \\
\text { Setyawati }\end{array}$ & 2020 & $\begin{array}{l}\text { The Effectiveness of Problem-Based Learning and Think Pair Share } \\
\text { Learning Models Assisted by Geogebra on Mathematical Problem } \\
\text { Solving Capabilities }\end{array}$ \\
\hline $\begin{array}{l}\text { Nur Hamidah, Lis Nur } \\
\text { Afidah, Lutfi Wahyu } \\
\text { Setyowati, Sutini, \& } \\
\text { Junaedi }\end{array}$ & 2020 & $\begin{array}{l}\text { The Effect of Geogebra Learning Media on Quadratic Function Material } \\
\text { on the Motivation and Learning Outcomes of Students }\end{array}$ \\
\hline $\begin{array}{l}\text { N. Mayasary, C. } \\
\text { Hasanudin, \& A. } \\
\text { Fitrianingsih }\end{array}$ & 2020 & $\begin{array}{l}\text { The use of wingeom software in geometry subject, how is the learning } \\
\text { outcomes of junior high school students? }\end{array}$ \\
\hline
\end{tabular}

